\title{
Research and Commentaries on Buddhism by Norwegian Missionary Karl Ludvig Reichelt
}

\author{
SUN YIPING \\ Nanjing University \\ syp18@nju.edu.cn
}

Keywords: Karl Ludvig Reichelt, Buddhist research, Christian Centre, religious dialogues

DOI: https://dx.doi.org/10.15239/hijbs.01.01.05

\begin{abstract}
During the Republic of China period, the Norwegian missionary Karl Ludvig Reichelt 艾香德 (1877-1952) and his family were sent to China by the Norwegian Missionary Society (Nuowei wai bang chuan jiaohui 挪威外邦傳教會). Influenced by the period's revival of Buddhist culture, and especially the lay Buddhism, Reichelt gradually realised that 'without studying Buddhism, one hasn't the means to evangelise'. As a result, he diligently studied and came to an understanding of Buddhism. He even established 'Christian Centres' (Jidujiao conglin 基督教叢林) in Nanjing and later Hong Kong in order to spread Christianity throughout China by a Buddhist-inspired method. He also launched the 'Religious Unity Movement' (Zongjiao lianhe yundong 宗教聯合運動), which promoted mutual understanding and dialogue between religions. The Buddhism-inspired methods used by Reichelt to disseminate Christianity have always led to a great deal of controversy, but it cannot be disputed that he advanced understanding between European and Eastern cultures and fostered interactions between Buddhism and Christianity. The religious dialogues he fostered have had a positive impact that continues to this day.
\end{abstract}


Karl Ludvig Reichelt (1877-1952; known in China by the Chinese Lname Ai Xiangde 艾香德) was a Norwegian missionary who came to China to spread Christianity during the Republic of China period. He was influenced by the period's revival of Buddhist culture, and especially lay Buddhism, which led him to the realisation that 'without studying Buddhism, one hasn't the means to evangelise'. As a result, he sought to disseminate Christianity throughout China by studying Buddhism, came to an understanding of the religion, and began to champion Christianity in a style influenced by Buddhist culture. $\mathrm{He}$ also launched the 'Religious Unity Movement' (Zongjiao lianhe yundong 宗教聯合運動) to promote mutual understanding and discourse between the two religions. This paper attempts to research Buddhism from three perspectives: Karl Ludvig Reichelt's Buddhist-influenced efforts at spreading Christianity, the Buddhist-styled Christian Centre (Jidujiao conglin 基督教叢林) Reichelt founded to spread Christianity, and the 'Religious Unity Movement' that he launched to promote dialogue between Christianity and Buddhism. This paper provides a general account of Reichelt's research on Buddhism, and all suggestions or advice from others would be highly appreciated.

\section{Influenced by Lay Buddhism and Studying Buddhism to Spread Christianity}

In 1903, Karl Ludvig Reichelt and his family were sent to China by the Norwegian Missionary Society. In December of that year, he began work as an educator and Christian missionary in Ningxiang 寧鄉 County, Hunan Province. The Chinese Buddhists with whom he made contact piqued a deep interest in him. After he and his fiancée, Anna Dorothea Gerhardsen (known in China by her Chinese name Ge Haisi 葛海 絲), were married in 1905 in the town of Guling 牯嶺 at Mount Lu 盧山, he returned to Ningxiang County for work. But the church in Ningxiang found itself caught in the path of warfare and was destroyed in 1910. The following year, Reichelt returned to Norway to give a report on his work. ${ }^{1}$

1 Anonymous, Shijie datong, 9. 
Reichelt's first trip to China coincided with the end of the Qing Dynasty and the beginning of the Republic of China. It was a time when the development of Chinese Buddhism was approaching a new phase. In 1911, Sun Yat-sen 孫逸仙 (1886-1925) led the Xinhai Revolution (Xinhai geming 辛亥革命), which was supported by the people. A great many monks also actively supported and participated in this struggle against feudalistic autocracy. After the Republic of China's government was established, Sun Yat-sen paid special attention to the peculiar revolutionary force provided by Buddhist monks. He greatly appreciated Master Zongyang 宗仰 (1861-1921) who generously offered financial support, with whom he often discussed the revolutionary project. In 1919, Sun Yat-sen had 10,000 silver coins sent to Nanjing's Qixia Temple 栖霞寺, which Master Zongyang was in charge of, to help with renovations. In 1912, such lay Buddhists as Li Zhenggang 李證剛 (dates unknown) set up the Buddhist Association. When they applied for registration with the government, Sun Yat-sen personally sent a letter to the Buddhist Association's interim president wherein he expressed his support for the Buddhist objective of 'seeking eternal world peace and providing complete happiness to all sentient beings'. He also elaborated upon the principles of separation of religion and state, as well as the notion of religious freedom. This helped to foster the development of Buddhism and promoted the flourishing of lay Buddhism during the Republic of China period. ${ }^{2}$

After Buddhism spread into China, the at-home Buddhists who accepted the 'three refuges' (san guiyi 三皈依) (that is, taking refuge in the Buddha, Dharma, and the Sangha) and the 'five precepts' (wujie 五戒) (namely, to refrain from killing, stealing, lying, engaging in improper sexual conduct, and consuming intoxicants), as opposed to from within the Sangha, became known as 'lay Buddhists'. Since there has historically been no shortage of lay Buddhists, lay Buddhism gradually developed into an important cultural phenomenon in Chinese society. By the Qing Dynasty, Buddhist circles had deteriorated considerably, but the research of Buddhism and the propaga-

2 Hong, Zhongguo fojiao wenhua licheng, 275-76. 
tion of Dharma by lay Buddhists became an important driving force for the development of Buddhism.

A notable aspect of the development of Chinese Buddhism during the Republic of China period is that lay Buddhists took on such a crucial cultural role in propagating Buddhism, and lay Buddhists founded a great number of Buddhist organisations. These organisations played a major role in Buddhist studies, establishing Buddhist publications, and taking on charitable projects for society. They not only promoted the rapid development of modern Buddhist culture but also attracted the attention of Western missionaries in China. Karl Ludvig Reichelt, in particular, was deeply influenced by their efforts.

In traditional Chinese Buddhism, monks were people who left their families out of faith to practice Buddhism. They constantly assumed the responsibility of promoting the development of Buddhism. Lay Buddhists were those who believed in the dharma and practised self-cultivation from their homes. They upheld the true dharma and they were the protectors of the Buddha's teachings. When lay Buddhism came to prominence in the modern era, it elevated Buddhism's overall status in society, and it also placed a great deal of pressure on the Sangha. Within the Buddhist circles of that time, there were some instances of corruption and decline that were criticised by lay Buddhists. The arrows of disapproval launched by lay Buddhists more often than not hit the monastics in places where it hurt.

As the number of Buddhist organisations led by lay Buddhists rapidly increased, the influence they exerted on ordinary believers became ever greater. There were several forward-looking Buddhist figures-including Master Jing’an 敬安 (1852-1912), Master Yuexia 月霞 (1858-1917), and Master Dixian 諦閑 (1858-1932)—who began to call loudly for the reform of Buddhism. Taixu 太虛 (18901947) in particular made tireless efforts to connect with the needs of the era in an effort to revitalise the religion. Master Taixu studied Buddhism with the lay Buddhist Yang Wenhui 楊文會 (1837-1911) during his adolescence, and he was later influenced by revolutionary theories, which left him resolved that 'Buddhism can save the nation and the world'. In 1913, at Master Jingan's memorial service, Master Taixu proposed the three revolutionary positions of religious doctrine (jiaoli 教理), religious regulation (jiaozhi 教制), and property 
of the monastery (jiaochan 教產)', and he called for Buddhism to reform itself of its own accord. This began a new chapter for the rejuvenation movement of Buddhist culture in the modern era. Among the several lay Buddhist scholars of this movement, certain figures, like Yang Wenhui and Ouyang Jingwu 歐陽竟無 (1870-1943), played indelible roles.

In 1866, Yang Wenhui established the Jinling Buddhist Press 金 陵刻經處 in Nanjing, and several years later in 1922, Ouyang Jingwu founded the Chinese Inner Studies Institute 支那内學院 on the basis of the Jinling Buddhist Press. The profundities of Buddhist theory, the depths of the Buddhist doctrine, and the miraculous uses of Buddhist teachings piqued the interest of numerous scholars and public figures in Buddhism. Such individuals as Tan Sitong 譚嗣同 (1865-1898), Liang Qichao 梁啓超 (1873-1929), Liang Shuming 梁漱溟 (1893-1988), Lu Xun 魯迅 (1881-1936), Zhang Taiyan 章太炎 (1869-1936), Xiong Shili 熊十力 (1885-1968), Tang Junyi 唐君毅 (1909-1978), and Lü Cheng 呂澂 (1896-1989) all came to the Chinese Inner Studies Institute to hear lectures on Buddhist studies, and Nanjing accordingly became a region where lay Buddhism thrived during the Republic of China period. At that time,

Given the trajectory of Chinese Buddhism, the superstitious activities surrounding temples will gradually decrease and likely disappear. Lay Buddhists are performing more research on the religion, and they are completing more work by the day. Today, as to the intellectual class, the vast majority of the intellectuals regard Buddhist studies favourably. ${ }^{3}$

Lay Buddhism also influenced a few Christian missionaries, and they gradually became aware that 'without studying Buddhism, one hasn't the means to evangelise'. ${ }^{4}$ Karl Ludvig Reichelt was among the ranks of those who shared these sentiments.

Karl Ludvig Reichelt recognised that 'the most widespread re-

3 Wang, Jidu tu zhi foxue yanjiu, 1.

$4 \quad$ Wang, 2. 
ligion with the most followers in China was Buddhism because, in terms of organisation and piety, it displayed the richest ideas. ${ }^{5}$ As a result, he contended that only by understanding Buddhism, especially lay Buddhism, could one do a more effective job at spreading Christianity. He took advantage of his trip home to report on his work, and he visited Sweden, Denmark, and Norway to deliver speeches in which he announced the significance of his efforts and the specifics of his plans. Additionally, he wrote a research piece in Norwegian on Chinese Buddhism. This work is called Truth and Tradition in Chinese Buddhism (Zhongguo Fojiao zhong de zhenli $y u$ chuantong 中國佛教中的真理與傳統). The original edition was published in Norway in 1922, and it contains the manuscripts to a number of speeches given by the author in 1921 when he was invited to Sweden's Uppsala University. These manuscripts were collated in Sweden and then published in book format.

On account of the fact that many Western university students were utterly unfamiliar with Chinese Buddhism, Reichelt provided them with a brief introduction that detailed some foundational information on Buddhism; however, this account came from the unique perspective of a Westerner who had an understanding of Buddhism in China. In the book, he gave extremely detailed introductions to the monk's ceremonies for worshiping the Buddha and their attitudes towards Buddhist scripture. It discussed how the monks were exceptionally respectful when they touched the scrolls of Buddhist scripture and how every day they recited scriptures during their gongke 功課. It told of how they wrapped the scriptures in red embroidered bags before placing them under the pedestal of the statue of Amitabha Buddha. The work also mentioned that when they used the scrolls of scripture in their rooms, they often stored them within a small book box. ${ }^{6}$ Such meticulous observations and specific descriptions were seldom made by Chinese writers.

In 1927, The Commercial Press published an English version of this book under the name of The Teachings and Origins of Chinese

\footnotetext{
5 Reichelt, 'Introduction', 1.

6 Reichelt, Truth and Tradition, 249.
} 
Buddhism (Zhina Fojiao jiaoli yu yuanliu 支那佛教教理與源流). The cover featured the author's Chinese name (Ai Xiangde 艾香德) along with an English subtitle that reads 'A Study of Chinese Mahayana Buddhism'. After the book was published, it sold exceptionally well, and by 1932 three additional editions had already been released. In each new edition, the author added more material to the work. Then in 1932 the Japanese army blew up the Commercial Press, and the latest edition of the book was destroyed along with the building. But by 1934 the Commercial Press had already reproduced a fourth typesetting for the book's publication, and Reichelt took advantage of this republishing to make additional revisions to the text and add illustrations. Compared with the older editions, this version was a far more comprehensive work. When the Commercial Press published it in China, it surprisingly chose to do so in English and not in Chinese. This is perhaps because the work was written for a Western audience-especially Christian missionaries. The book was repeatedly reprinted until the early twentieth century, serving the pressing needs of Westerners with a desire to understand China and Chinese Buddhism.

Karl Ludvig Reichelt's rigorous study of Buddhism even touched on Hetuvidya (yinming xue 因明學), which is the most difficult topic in Buddhist studies. Even Wang Zhixin 王治心 (1881-1968) - a religious scholar, historian of the Christian Church, and author of The Outline of Chinese Religious Thought History (Zhongguo zongjiao sixiang shi dagang 中國宗教思想史大綱)—was influenced by Reichelt, and as a result he went to the Chinese Inner Studies Institute specially to gain a better understanding of Buddhist studies from Ouyang Jingwu, Lü Cheng, and Wang Enyang 王恩洋 (1897-1964). Wang Zhixin later wrote Research on Christian Studies of Buddhism (Jidu tu zhi foxue yanjiu 基督徒之佛學研究). Seeking answers to a number of difficulties he had encountered concerning Hetuvidyā, Wang Zhixin spent two weeks attending Lü Cheng's lecture of Hetuvidyā at the Institute. He then stated, 'Being enlightened by Mr. Lü, he provided me with a rough look into the subject. Afterwards, I returned home, restarted my study of Hetuvidyā, and gained some new insights'. ${ }^{7}$ Later,

7 Wang, Jidu tu zhi foxue yanjiu, 62. 
Reichelt collated Research on Christian Studies of Buddhism and even wrote an accompanying English preface. Spanning more than a dozen pages and discussing the essentials of Hetuvidyā, the work was full of Buddhist terminology, and the fact that Reichelt was able to collate the work makes it clear that he had performed ample research on the topic of Hetuvidya. ${ }^{8}$

\section{Establishing the Christian Centre: Spreading the Gospel in a Buddhist Way}

After spending a few years studying in Europe, Karl Ludvig Reichelt returned to China to take up a teaching position at a Lutheran seminary near Hankou 漢口. He was there until 1920 when he again returned to his home country to report on his work. While teaching at the seminary, Reichelt regularly used his vacation time to tour Buddhist and Daoist temples. He even stayed at Daoist temples and Buddhist temples and studied Buddhist and Daoist classics with believers of both religions, discussing questions of life and religion. Reichelt drew on these experiences to, on one hand, better understand the doctrines and ceremonies of these religions; on the other, he also sought to proactively spread the Christian faith and the notion that Jesus is the saviour of humanity unto Buddhist monks and Daoist priests. Throughout this process, Reichelt came to believe that people from different religious backgrounds should foster a mutual understanding, develop shared sentiments, and forge friendships. As a result, he diligently studied Chinese and researched the nation's religions, especially Mahayana Buddhism, by reading Chinese classics. On the eve before Reichelt returned to his home nation to report on his work, he paid a visit to a Buddhist temple in Nanjing. This trip caused him to recognise how Buddhist faith could be put into practice within Christianity. It was on this very occasion that he preached the gospel to a monk who then allowed Reichelt to baptise him, which was the first time this had happened

8 Gao, 'Waiguo zhexuejia'. 
since he'd gone to China. ' This gave Reichelt newfound confidence in his efforts to spread Christianity to Buddhists. Consequently, when he returned home to report on his work, he took complete advantage of the opportunity to make clear to the Norwegian Missionary Society the significance of the good tidings that Christianity had spread among Buddhists.' ${ }^{\text {10 }}$

In 1922, Karl Ludvig Reichelt once again returned to China to visit the famous Chinese Inner Studies Institute. In Chinese, the characters used to represent 'Chinese' (Zhina 支那) in the 'Chinese Inner Studies Institute' (Zhina nei xueyuan 支那内學院) are derived from an ancient Indian way of referring to China, while Buddhism refers to itself as 'inner studies' (nei xue 内學)—such is the etymology behind how the Institute was named. It set its mission as 'propagating Buddhist studies and cultivating talented individuals to benefit the world'. The Institute recruited students and taught them about such important scriptures teachings as those of the Consciousness-Only school. It advocated for lay Buddhists serving as the heads of Dharma upholding and protecting Dharma and promoted the development of lay Buddhist culture in the modern era. In Reichelt's work The Teachings and Origins of Chinese Buddhism, he gives descriptions of the Chinese Inner Studies Institute and the lay Buddhist Ouyang Jingwu. Reichelt refers to the Institute as an 'aristocratic form' of Buddhist school, and he characterises it as a place where one can encounter a group of educated Chinese men who were born into good families and may even be able to study a little Sanskrit. He notes that the Institute was brimming with a graceful scholarly mood and a cultured spirit and that every single person who joins the Institute must study for a full four years before they can be deemed qualified as a person who has researched Buddhism. However, considered from the per-

9 In 1921 Karl Ludvig Reichelt used English to write A Brief Sketch of the Historical Relation Between Mabayana Buddhism and Christianity, which was revised by Li Lude and had a prologue written by Li Yuan and Chinese headings written by Master Kuandu. It was renamed in Chinese and published by the American Presbyterian Mission Press in Shanghai.

10 Lai and He, 'Kan Zhongguo Jidujiao de weilai fazhan'. 
spective of a missionary, Reichelt also believed that the Chinese Inner Studies Institute attached special importance to scientific research and clearly lacked a religious zeal. This manifested itself in the fact that the entire Institute, from top to bottom, rarely performed daily Buddhist gongke, and that every person had their own comprehension and way of practising the religion. This is likely the same basic impression that the Institute made on others by the tendency of putting emphasis on Buddhist research. ${ }^{11}$

Perhaps because he was influenced by lay Buddhists and the Chinese Inner Studies Institute, Karl Ludvig Reichelt established the Jing Fong Shan Christian Centre (Jingfong shan Jidujiao conglin 景風山基督教叢林, pronounced 'Jingfeng shan' in Mandarin Chinese) outside Nanjing's Heping Gate (Heping men 和平門) in 1922. He focused the majority of his energy on the task of spreading the Christian gospel to Buddhists, and along with preaching to the general populace, he also attracted Buddhists, Daoists, and lay Buddhists to his Christian Centre for their studies. It was primarily these religious groups that he sought to evangelise, which put the Religious Unity Movement into practice. As a result, the way that Jing Fong Shan was referred to as a 'Christian Centre' (conglin 叢 林) instead of simply calling it a 'church' is to employ Buddhist terminology to dispel Buddhists' conflicted feelings about Christianity. Reichelt proposed that for Christianity to enter into the lives of the Chinese people, the church would need to marry itself with Chinese traditions and wash away any hint of Western culture; that is, it needed to take on Chinese characteristics. He even advocated for Christian liturgy to absorb some elements of Buddhism. For example, the pastor could wear Buddhist clothes while preaching, quote some parts of Buddhist scripture to interpret Christian teachings, and during prayer they could sound a bell (qiaozong 敲鐘), burn incense, light candles, kneel to read litany, and sing hymns of Chinese melodies. The daily meals provided at Jing Fong Shan were also entirely vegetarian. 'Dr. Reichelt met with figures of the Buddhist world in Nanjing over the course of six to seven years. In terms of

\footnotetext{
11 Gao, 'Waiguo zhexuejia'.
} 
the number of monks he baptised, although the number was not great, there were still perhaps as many as 1,000 who visited him yearly to ask about Christianity. Hence, it cannot be said that he had merely a small influence. ${ }^{12}$ The Jing Fong Shan founded by Reichelt turned into a Christian centre imbued with a certain Buddhist tint, which attracted people of varying social backgrounds to pay a visit. Was this the result of Christianity's efforts to convert Buddhists? Or was this the result of Christianity being influenced by Chinese Buddhism, leading to the emergence of Buddhist tendencies? There are the two sides of the same coin, but what is certain is that a combination of these two tendencies promoted dialogue and a form of mutual understanding between the two religions of Christianity and Buddhism.

\section{Launching the Religious Unity Movement: Promoting Dialogue Between Religions}

In order to better understand Buddhism, Karl Ludvig Reichelt actively developed relationships with Buddhist monks and lay Buddhists. As explained in Record of Master Taixu (Taixu dashi nianpu 太虛大師年譜), from the 13th to the 15th of July, 1924, an opening ceremony for the 'World Buddhist Unity Society' (Shijie Fojiao lianhe hui 世界佛教聯合會), as established by Master Taixu himself, was held at Dalin Temple 大林寺 on Mount Lu. More than 10 representatives from around the nation attended, including Liaochen 了塵 of Hubei, Xingxiu 性修 of Hunan, Changxing 常惺 (1896-1939) of Jiangsu, and Zhu'an 箨庵 of Anhui, as well as such lay Buddhists as Li Zhenggang of Jiangxi, Wang Sufang 王肅方 of Sichuan, Wu Zhongying 武仲英 of Zhejiang, Zhang Chunyi 張純一 (1871-1955) of Shanghai, and more. Sasaki Jōin 佐伯定胤 (1867-1952) of Japan’s Hossō sect and Kimura Taiken 木村泰賢 (1881-1930) of Tokyo Imperial University were also present, and Mizuno Baigyō 水野梅曉 (18771949) and Shi Weihuan 史維煥 (1895-1945) served as the event's Jap-

\footnotetext{
12 Xiao, 'Daofengshan', 13.
} 
anese translators. There were also several believers in Buddhism from England, Germany, Finland, and France, along with Christians like Reichelt who joined the conference. At that time, Reichelt represented the rare instance of a Christian Protestant who had actively gained an understanding of Buddhism. When he and Taixu met at Mount $\mathrm{Lu}$, they immediately took to one another like old friends and began to frequently discuss Christianity and Buddhism. ${ }^{13}$ It was precisely through such mutual discourses with individuals bearing different perspectives that Reichelt was able to gain a deeper understanding of religions outside of Christianity. During the lecture series entitled Introduction to Religions that Reichelt provided at Nanking Theological Seminary in 1925, he discarded parochial prejudices and stressed that a path to truth should be sought out from among the five religions of Christianity, Buddhism, Daoism, Confucianism, and Islam (Hui). He also stressed in the lecture that the essence of all these ideologies should be absorbed, especially the prajñ $\bar{a}$ wisdom provided by Mahayana Buddhism, revealing an open mind and harmonious view. The transcript to this lecture was recorded and arranged into Chinese by Huang Jingren 黃景仁, and it was later published by the Society for the Diffusion of Christian and General Knowledge Among the Chinese (Shanghai guang xuehui 上海廣學會) in 1931.

Although Reichelt was from the Western world, he had a deep love of Chinese culture. By gaining an understanding of the tremendous impact that Buddhism and Daoism had left on Chinese religions, he came to advocate for Christians working to befriend those of different faiths. He believed that this should begin with Buddhism and Daoism before expanding to include other religions. This is because, looking at China from a historical perspective, the nation had proved capable of tolerating all kinds of religions Chinese doctrines. No religious war ever emerged in Chinese history, therefore it is rather suitable to develop the discourses and exchanges between various religions. Only the barriers between Christianity and Chinese religions were broken, a mutual understanding among Christianity and Buddhism and Daoism could be reached, and then a path to spreading Christianity in China could

13 Reichelt, Zongjiao gailun, 167. 
be established. Reichelt launched the 'Religious Unity Movement' in 1920, and although it was based upon dialogue between members of different religions, this kind of unity was, in Reichelt's words, one forged between religious figures but not a merging of religions.

Shortly after the Northern Expedition military campaign began, Nanjing's Jing Fong Shan house was caught in the flames of warfare, and Reichelt and his followers went to Shanghai for three years. In 1930, Reichelt moved his work from China's mainland to Hong Kong, where he purchased a house and set up the 'Tao Fong Shan Christian Centre' (in Mandarin Chinese: Daofeng shan Jidujiao conglin 道風山基督教叢林) at Sha Tin 沙田, a place where people can study religions and cultivate mind and body. In order to attract Buddhists and Daoists to Tao Fong Shan, Reichelt invited the famous Danish architect Johannes Prip Moller 艾術華 (1889-1943) to help design the huge, Chinese-styled building complex. The complex's logo is a cross situated atop a religious lotus blossom, which was a symbol for Christianity being passed on to Buddhists.

After construction was completed on Tao Fong Shan in 1933, Reichelt founded Tian Feng Shan 天風山 in Hangzhou in 1935, and he later established similar religious centres in such places as Dali 大理 in Yunnan Province, Mount Emei 峨眉山 in Sichuan, and Hengyang 衡 陽 in Hunan. ${ }^{14}$ Reichelt promoted religious dialogue, and especially in the case of Christianity and Buddhism, he was the earliest missionary to carry out such a practice. He also set up the 'Religious Culture Friendship Federation' (Zongjiao wenhua youyi she 宗教文化友誼 社) to serve as an organisation for researching and forging friendships on Tao Fong Shan. Every Sunday night he invited religious studies specialists to take turns making speeches, allowing each other to gain a mutual understanding and forge interpersonal friendships. ${ }^{15}$ Today, 'branches of these purely religious friendship-based movements are established across the whole world in every country. ${ }^{316}$

Beginning in the modern era, the methods lay Buddhists em-

\footnotetext{
14 Thelle, 'Brief History', 9.

15 Lo, 'Preface', 5.

16 Xiao, 'Preface', 3.
} 
ployed to incite the religion's revival and the resulting effect on Chinese intellectuals caused Buddhism's status to rise in the minds of Christian missionaries. They also allowed Reichelt to trim down the hedges separating religions and gave him the impetus to vigorously study Buddhism. Early Christian missionaries to China at the end of the Ming and the beginning of the Qing Dynasty also shared the notion that only by understanding traditional Chinese culture, and especially Buddhism, could the gospel be more effectively spread. For example, the early missionaries Matteo Ricci 利瑪竇 (1552-1610) and Michele Ruggieri 羅明堅 (1543-1607) shaved their heads and wore a kạsāya robe like Buddhist monks, which was well received by Buddhists; 12 years after Matteo Ricci arrived in Zhaoqing 肇慶, he finally changed to Confucian attire and let his hair and beard grow long. ${ }^{17}$ However, compared with these early missionaries, the Jing Fong Shan and the later Tao Fong Shan Christian Centre founded by Reichelt demonstrated a deeper understanding of Buddhism both in terms of content and appearance. The Tao Fong Shan Christian Centre that exists today in Hong Kong is a temple that employs neither the Western dome or spire elements of church design; rather, it uses the Buddhist style of a circular altar (yuantan 圓壇). There is also the Yunshui Hall 雲水堂 that provides lodgings for believers, travelling guests, and visiting scholars. Although it looks like a Chinese Buddhist temple from an external standpoint, the contents at its core are decidedly Christian in nature.

Such efforts to evangelise by making use of Buddhist-inspired methods have consistently received a mixture of praise and condemnation. On one hand, they have been praised by some Western missionaries and Chinese Buddhists due to the promotion of civilised dialogues and peaceful interactions between multiple religions. On the other hand, conservative members of the Norwegian Missionary Society and the Northern Europe Foreign Missions Union (Beiou chahui lianhehui 北歐差會聯合會), who offered the support and subsidisation, have firmly opposed Reichelt's missionary efforts in China because of their deviation from the traditional Christian stance on

\footnotetext{
17 Gernet, Christian Impact, 56.
} 
evangelisation. He suffered even more from the firm resistance of Buddhist groups that believed Reichelt only advocated for religious unity with the ultimate objective of transforming Buddhists into Christians. As a result, questions related to whether or not Chinese Christianity should be 'localised' in such a way, as well as how to localise Christianity for China, have persisted well into the present day.

Karl Ludvig Reichelt proposed discussion between religions and creating unity between them. His theoretical research and actual practices touched on Christianity and Buddhism, and these explorations proved to be of great value. Although he was met with criticism and misunderstanding from both sides, Reichelt nevertheless persisted with his objective. In 1952, Reichelt passed away at Tao Fong Shan in Hong Kong. Later generations evaluated him as follows:

Among Western figures of the modern era, it is impossible to find another who was like him-who was able to have such a deep, penetrating understanding of Buddhism and cause Christianity to have such a great impact on Buddhist monks and leaders. ${ }^{18}$

Today, the question proposed by Reichelt regarding religious dialogue and unification has already developed into an international cultural phenomenon worthy of attention. Consequently, revisiting Reichelt's religious dialogues appears to offer even greater theoretical value and practical significance.

\section{Bibliography}

Zhenli tansuo-Ai Xiangde boshi baisui mingdan jinian zhuanji, taiwan zongjiao wenhua youyi she 1976 nianban 真理探索-— 艾香德博士百年冥誕紀念專集, 臺灣宗教文化友誼社1976年版 [The Anthology of the Articles for the $100^{\text {th }}$ Anniversary of Dr. K. L. Reichelt, 1976 Edition]. Anonymous (compiled). Taipei: Taiwan Zongjiao Wenhua Youyishe 臺灣宗教文化友誼社, 1976.

18 Wei, 'Introduction'. 
Gao Shanshan 高山杉. 'Waiguo zhexuejia he zongjiaoxuejia bixia de Zhina Neixue Yuan’ 外國哲學家和宗教學家筆下的支那内學院 [Writings by Foreign Philosophers and Religious Studies Scholars on the Chinese Inner Studies Institute]. Shijie zhexue 世界哲學 [World Philosophy] 3 (2006): 63-72.

Gernet, Jaques. China and the Christian Impact: A Conflict of Cultures. Translated by Janet Llyod. Cambridge: Cambridge University Press, 1985.

Hong Xiuping 洪修平. Zhongguo fojiao wenhua licheng 中國佛教文 化歷程 [The Course of Chinese Buddhist Culture]. Expanded and revised edition. Nanjing: Jiangsu jiaoyu chuban she 江苏教育 出版社, 2005.

Lai Pinchao 賴品超, and He Jianming 何建明. 'Kan Zhongguo jidujiao de weilai fazhan' 看中國基督教的未來發展 [Outlook on Future Development of Christianity in China]. In Jidu zongjiao yanjiu 基督宗教研究 [Christian research], 3rd edition, edited by Zhuo Xinping 卓新平 and Xu Zhiwei 許志偉. Beijing: Zongiiao wenhua chuban she 宗教文化出版社 [Religion Culture Publishing House], 2001.

Lo, Archbishop Stanislaus Kuang. 'Preface'. In Zhenli tansuoaixiangde boshi baisui mingdan jinian zhuanji, taiwan zongjiao Aixiangde youyi she 1976 nianban 真理探索——艾香德博士百 年冥誕紀念專集, 臺灣宗教文化友誼社1976年版 [The Anthology of the Articles for the $100^{\text {th }}$ Anniversary of Dr. K. L. Reichelt, 1976 Edition]. Anonymous (compiled). Taipei: Taiwan Zongjiao Wenhua Youyishe 臺灣宗教文化友誼社, 1976.

Reichelt, Karl Ludvig. 'Introduction'. In The Transformed Abbot. London: Lutterworth Press, 1954.

- - - The Transformed Abbot. London: Lutterworth Press, 1959.

- - - Truth and Tradition in Chinese Buddhism: A Study of Chinese Mahayana Buddhism. 1934 Edition. Shanghai: The Commercial Press, 1934.

- - - Zongjiao gailun 宗教概論 [Introduction to Religions]. Shanghai: Society for the Diffusion of Christian and General Knowledge Among the Chinese, 1931.

Thelle, Notto N. 'A Brief History on Dr. Reichelt'. In Zhenli tansuo-Ai Xiangde boshi baisui mingdan jinian zhuanji, 
taiwan zongjiao wenhua youyi she 1976 nianban 真理探索—— 艾香德博士百年冥誕紀念專集, 臺灣宗教文化友誼社1976年版 [The Anthology of the Articles for the $100^{\text {th }}$ Anniversary of zDr. K. L. Reichelt, 1976 Edition]. Anonymous (compiled). Taipei: Taiwan Zongjiao Wenhua Youyishe 臺灣宗教文化友誼社, 1976.

Wang Zhixin 王治心.Jidu tu zhi Foxue yanjiu 基督徒之佛學研究 [Research on Christian Studies of Buddhism]. Shanghai: Society for the Diffusion of Christian and General Knowledge Among the Chinese, 1924.

Wei Jingshi 韋經世. 'Introduction'. In The Transformed Abbot, by Karl Ludvig Reichelt. London: Lutterworth Press, 1954.

Xiao Shiyi 蕭師毅. 'Daofengshan yu jianglai' 道風山與將來 [Tao Fong Shan and the Future]. In Zhenli tansuo-Ai Xiangde boshi baisui mingdan jinian zhuanji, taiwan zongjiao wenhua youyi she 1976 nianban 真理探索——艾香德博士百年冥誕紀念專集, 臺灣宗教文化友誼社1976年版 [The Anthology of the Articles for the $100^{\text {th }}$ Anniversary of Dr. K. L. Reichelt, 1976 Edition]. Anonymous (compiled). Taipei: Taiwan Zongjiao Wenhua Youyishe 臺灣宗教文化友誼社, 1976.

Xiao Tianshi. 'Preface'. In Zhenli tansuo-Ai Xiangde boshi baisui mingdan jinian zhuanji, taiwan zongjiao wenbua youyi she 1976 nianban 真理探索——艾香德博士百年冥誕紀念專集， 臺灣宗教文化友誼社1976年版 [The Anthology of the Articles for the $100^{\text {th }}$ Anniversary of Dr. K. L. Reichelt, 1976 Edition]. Anonymous (compiled). Taipei: Taiwan Zongjiao Wenhua Youyishe 臺灣宗教文化友誼社, 1976. 